\title{
Overview of Phytochemical and Pharmacological of Gandarussa Extract (Justicia Gendarussa Burm)
}

Vina Aulia Putri, Zulharmita, Ridho Asra, Boy Chandra*

Sekolah Tinggi Ilmu Farmasi (STIFARM) Padang

\section{Article History \\ Received: 20.09.2020 \\ Accepted: 09.10.2020 \\ Published: 17.10.2020}

Journal homepage:

https://www.easpublisher.com/easipp

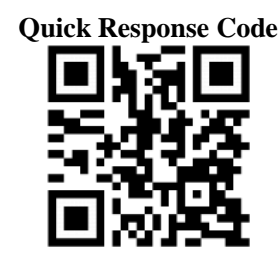

Abstract: Gandarussa plant (Justicia gendarussa Burm.F.) was a herbal plant that contains chemical compounds such as alkaloids, saponins, flavonoids, polyphenols, essential oils, tannins and steroids. The presence of these chemical compounds can be used as medicinal ingredients, namely headaches, rheumatism and sprains. Justicia gendarussa Burm.F. has long been used as an anti-inflammatory and pharmacologically, this plant has been reported that have antibacterial, analgesic, anthelmintic, anti-cancer, anti-inflammatory, antioxidant, anti-HIV, toxicity, sedative hypnotic and male contraception drugs.

Keywords: Justicia gendarussa Burm.F., Phytochemical, Pharmacological.

Copyright (C) 2020 The Author(s): This is an open-access article distributed under the terms of the Creative Commons Attribution 4.0 International License (CC BY-NC 4.0) which permits unrestricted use, distribution, and reproduction in any medium for non-commercial use provided the original author and source are credited.

\section{INTRODUCTION}

Justicia Gendarussa Burm .F. included in the family Acanthaceae, which are scattered in Asia, such as China, Philippines, India, Indonesia, Malaysia, Sri Lanka, Pakistan, Thailand and the Andaman Islands. J.gendarussa grew wild in the forest or river embankments and can also be planted as a medicinal plant or hedge plant [1].

Gandarussa plant (Justicia gendarusa Burm.F.) was known by various regional names such as, Sumatera: Besi-besi (Aceh), Gandarussa (Melayu); Java: Handerasa (Sunda), Gonorusa (Sunda), Gondorusa (Central Java), Ghandarusa (Madura); Nusa Tenggara: Gandarisa (Bima,), Puli (Maluku) [2].

Justicia gendarussa classification [3]

$\begin{array}{ll}\text { Kingdom } & \text { : Plantae } \\ \text { Division } & \text { : Tracheophyta } \\ \text { Class } & \text { : Magnoliopsida } \\ \text { Order } & \text { : Lamiales } \\ \text { Family } & : \text { Acanthaceae } \\ \text { Genus } & : \text { Justicia } \\ \text { Species } & \text { : gendarussa }\end{array}$

The morphology of Justicia gendarussa is a shrub, erect, up to $2 \mathrm{~m}$ in height. The stem is rectangular, woody, the young leaves are dark purple and when the leaves are old they turn shiny brown (Figure 1). J.gendarussa has single lanceolate leaves, 3$12 \mathrm{~cm}$ length, $1.5-3.5 \mathrm{~cm}$ width, pinnate, opposite, flat leaf edges tapered, and dark green leaf has short stalk (Figure 2). J.gendarussa has small white flowers that arranged in the form of malay or closed grain, spread, and out of the tip of the stalk [2].

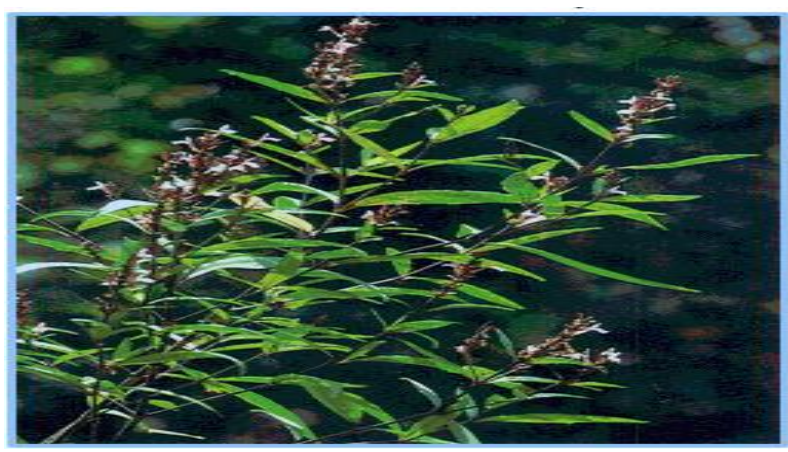

Fig-1: Gandarussa plant [4] 


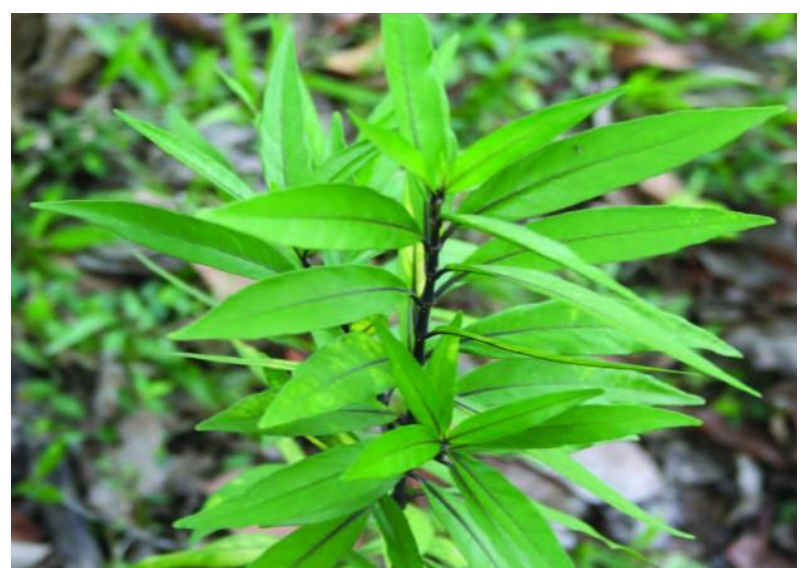

Fig-2: Gandarussa leaves [2]

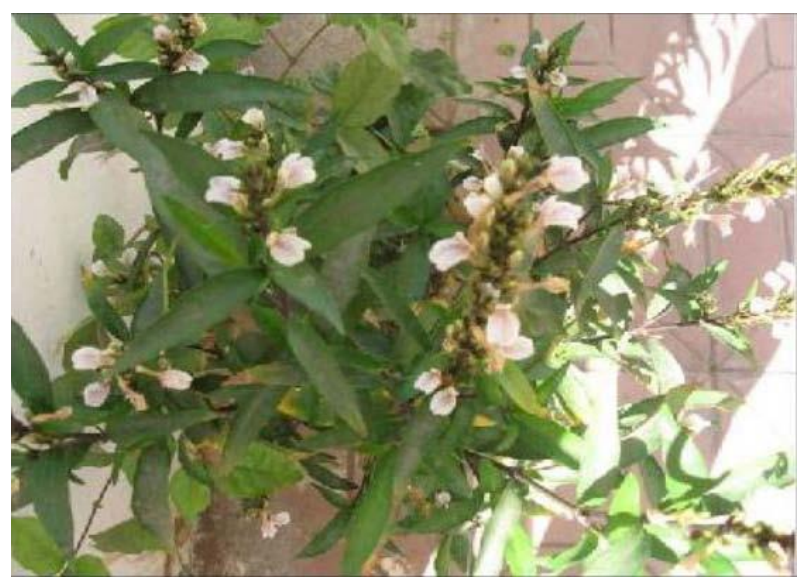

Fig-3: Gandarussa Flowers [2].

J.gendarussa is one of herbal plants used in the Ayuverda medical system. Ayuverda is one of the traditional healing methods that have been used for a long time. Ayuverda treatment helps to restore balance between body, heart, mind and environment. Treatment with the Ayuverda system can be started by consuming herbal ingredients, yoga, massage therapy, and meditation [3].

J.gendarussa has pharmacological effects such as fever, cough, jaundice, mouth sores, arthritis, cephalgia, hyplegia, facial paralysis, otalgia, hemicranias, bronchitis, chronic rheumatism, liver disorders, respiratory disorders, indigestion, antiinflammatory, and anti-cancer [5].

\section{Data Collection}

This review article used study literature technique by looking for theoretical references that were relevant to the cases or problems found. Collecting National and International articles with a span of 10 years (2010-2020) and using official books. The searching data in this review article used online media with trusted sites such as Google Scholar, Sciencedirect, Pupmed, Pupchem and NCBI with the search keyword "Justicia gendarussa Burm F".

\section{Phytochemical}

Screening of ethanol extract $\left(\mathrm{C}_{2} \mathrm{H}_{5} \mathrm{OH}\right)$ Gandarussa root (Justicia gendarusa Burm.F.) showed that were several chemical compounds such as carbohydrates, flavonoids, alkaloids and saponins. While hexane $\left(\mathrm{C}_{6} \mathrm{H}_{14}\right)$ and chloroform extract $\left(\mathrm{CHCl}_{3}\right)$ Gandarussa root (Justicia gendarusa Burm.F.) contained steroid [6]. Ethanol $\left(\mathrm{C}_{2} \mathrm{H}_{5} \mathrm{OH}\right)$ and aqueous extract $\left(\mathrm{H}_{2} \mathrm{O}\right)$ that obtained of Gandarussa stem (Justicia gendarusa Burm.F.) showed that there were tannins, flavonoids, glycosides, terpenoids and phenolic compounds [5].

Phytochemical screening of aqueous $\left(\mathrm{H}_{2} \mathrm{O}\right)$, ethanol $\left(\mathrm{C}_{2} \mathrm{H}_{5} \mathrm{OH}\right)$, hexane $\left(\mathrm{C}_{6} \mathrm{H}_{14}\right)$, and chloroform extract $\left(\mathrm{CHCl}_{3}\right)$ in Gandarussa leaves (Justicia gendarusa Burm.F.) showed that were glycosides, tannins, phenolic, flavonoids, terpenoids, carbohydrates, tannins, alkaloids and saponins [6, 5]. Chloroform $\left(\mathrm{CHCl}_{3}\right)$, methanol $\left(\mathrm{CH}_{3} \mathrm{OH}\right)$, and petrelium ether (pe) extract in Gandarussa leaves (Justicia gendarusa Burm.F.) showed that were flavonoids, essential oils, resins, and carbohydrates. J.gendarussa identified chemical elements from various leaf extracts using Gas Chromotography - Mass Spectrometer $G C-M S$, the result showed there were 23 bioactive phytochemical compounds [3]. J.gendarussa is a Phytol and $\beta$-sitosterol producer which included in the phenolic, terpenoid, and alkaloid parts. Phytol is acyclic terpen alcohols that were found as essential oils in aromatic plants $[7,8]$.

In Skudai and Muar areas, Gandarussa leaves (Justicia gendarusa Burm.F.) were collected to determine the distribution of 2 flavonoid compounds, namely naringenin and kaemprefol using Gas Chromotography - ionization (GC-IFD) detector analysis. The distribution of naringenin and kaemprefol of Gandarussa (Justicia gendarusa Burm.F.) was higher in old leaves than in young leaves, due to physiological, environmental and soil geographic factors [9]

\section{Pharmacological \\ Anti-bacteria}

One of the pharmacological activities contained in Gandarussa (Justicia gendarusa Burm.F.) is antibacterial. Antibacterial is a compound that can control bacterial growth. This study was used to evaluate the antimicrobial activity by using disc diffusion and broth dilution methods. Sample of aqueous extract $\left(\mathrm{H}_{2} \mathrm{O}\right)$ of Gandarussa stem showed that the antibacterial activity can inhibit maximum the bacteria Shigella flexneri $(26.20 \mathrm{~mm})$, Proteus mirabilis $(24.50 \mathrm{~mm})$, Escherichia coli $(21.40 \mathrm{~mm})$ B. Subtilis $(20.25 \mathrm{~mm}), \quad S$. paratyphi $A(19.50 \mathrm{~mm})$ by both methods. Different from ethanol extract $\left(\mathrm{C}_{2} \mathrm{H}_{5} \mathrm{OH}\right)$ of Gandarussa stem has less inhibitory activity. An 
aqueous extract of Gandarussa leaves showed significant antimicrobial activity to Staphylococcus aureus $(26.33 \mathrm{~mm})$. In the ethanol extract $\left(\mathrm{C}_{2} \mathrm{H}_{5} \mathrm{OH}\right)$, Gandarussa leaves showed little inhibitory activity to some organisms [5]. Extracts of methanol, chloroform and petrelium ether of Gandarussa leaves showed that the antibacterial activity was strong to $P$. pneumonia and $P$. vulgaris [3].

This study stated (Justicia gendarussa Burm .F.) extracts and solvent fraction of methanol, petrilium ether (pe), carbon tetrachloride, chloroform, and water have antibacterial activity to B. cereus, B. subtillis, $S$. aureus, Straphylococcus aureus, Sarcina lutea, E. coli, Pseudomonas aeruginosa, Salmonella paratyphi, Shigella boydi, S. dysenteriae, Vibri mimicus, and Vibrio parahemolyticus [10].

Testing of the root, stem and leaves of Gandarussa (Justicia gendarussa Burm .F.) using ethanol extract $\left(\mathrm{C}_{2} \mathrm{H}_{5} \mathrm{OH}\right)$ disc diffusion method and broth macrodilution test was tested on four positive gram bacteria, namely $S$. epidermidis, $S$. pyogenes, $S$. aureus, dan $E$, faecalis. Six gram-negative bacteria, namely $S$, boydii, S,disentri, $S$, typhi, $P$, vulgaris, and E.coly showed moderate antibacterial activity against the tested bacteria. The hexane and chloroform extract showed relatively high antibacterial activity against the tested bacteria. Alkaloid compounds, flavonoids, and saponins in the Gandarussa plant (Justicia gendarussa Burm .F.) supported antimicrobial activity, such as alkaloids are known have antimicrobial that was anti parasitic. Antibacterial activity of flavonoid was able to form extracellular complex proteins, dissolves and complexes with bacterial cell walls. Saponins also participate in antimicrobial activity in pathogenic bacteria and fungi [6].

Gandarussa stem (Justicia gendarussa Burm .F.) which extracted using aqueous and hexane, was tested with antimicrobial such as Eschericha coli, Staphylococcus aureus and Candida albicans by the disc diffusion method. Aqueous extract of Gandarussa (Justicia gendarussa Burm .F.) showed the largest inhibition zone of $5 \mathrm{~mm}$ to Eschericha coli and $3 \mathrm{~mm}$ to Staphylococcus aureus at concentration of $50 \mu \mathrm{gm} / \mathrm{ml}$ and was more effective against Candida albican fungi than hexane extract [11].

\section{Anthelmintic}

Anthelmintic is a compound to eradicate worms and excreted it through the digestive tract. Gandarussa (Justicia gendarussa Burm .F.) is a plant that has anthelmintic activity with chemical compounds containing stigmasterol, lupeol, and 16-hydroxylupeol. Methanol extract of leaves and stems of Gandarussa (Justicia gendarussa Burm .F.) has anthelmintic activity. Testing of paralysis and death of Pheretima phosthuma worm was carried out with test concentrations of $10,20,30,40$ and $50 \mathrm{mg} / \mathrm{ml}$. The methanol extract of leaves with a concentration of 50 $\mathrm{mg} / \mathrm{ml}$ caused paralysis in worm at 35.3 minutes and death at 70.7 minutes. While the stem methanol extract caused paralysis in worm at 41.3 minutes and death at 89.3 minutes. Albendazole which was used as a positive control caused paralysis and death in worm at 17 and 48 minutes [12].

\section{Analgetic}

Gandarussa (Justicia gendarussa Burm .F.) is a plant that has activity as an analgesic with chemical compounds such as steroids, terpenoids, flavonoids, and alkaloids. An analgesic is compound or drug that was used to reduce pain or pain caused by various stimuli to the body, both mechanicals, chemical, and physical. Pain can cause damage to tissues that trigger the release of pain mediators such as bradykinin and prostaglandins which eventual activate pain receptors in peripheral nerves and was passed on to the brain. Research on the n-hexane fraction of Gandarussa leaves (Justicia gendarussa Burm .F.) has activity as an analgesic. The identification of the n-hexane fraction of gandarussa leaves (Justicia gendarussa Burm .F.) containing steroids and terpenoids that can stimulate lipomodulin protein biosynthesis which can inhibit the enzymatic phospholipase activity, was responsible enzyme for the release of arachidonic acid which blocks cycloogsigenation and lipooksigenase, inhibiting prostaglandins , leukotrienes, prostacyclin, and thromboxane [13]

\section{Anti inflamation}

Gandarussa (Justicia gendarussa Burm .F.) is a plant that has been used as a medicine to treat inflammation (anti-inflammatory). Since ancient times, inflammation is a complex biological response of blood tissues to harmful stimuli such as pathogens, cells that were damaged, or irritated. The ethanol extract of Gandarussa leaves (Justicia gendarussa Burm .F.) which was cold macerated has anti-inflammatory effect with concentration of $50-200 \mu \mathrm{g} / \mathrm{ml}$ which could weaken NO (Nitric Oxide) production and reduce MMP-9 gene expression in macrophages that induced with lipopolysaccharide (LPS) $1 \mu \mathrm{g}$. NO and MMP-9 have an important role in tissue damage and inflammation through degradation of matrix protein with proteolytic activity of cytokines. NO step produced by mecrophages without lipopolysacride induction (LPS) showed no significant results compared to treatment. In this study, dexamethasone as a standard drug which inhibited $85 \%$ of NO production in macrophage cells [14].

Methanol extract of Gandarussa root (Justicia gendarussa Burm .F.) showed anti-inflammatory activity, the dose used was $100 \mathrm{mg} / \mathrm{kg}$ significantly inhibited edema formation 5 hours after carrageenan induction. It showed that the root extract of gandarussa (Justicia gendarussa Burm .F.) has high edematogenic that caused total cycloxysigenase activity, providing 
anti-inflammatory effects by reducing prostaglandin production through inhibition of COX and key enzymes in prostaglandin synthesis [15].

Extract of Gandarussa leaves (Justicia gendarussa Burm .F.) contained Phytol compound which have anti-inflammatory activity by releasing histamine $(26.92 \%)$, serotonin and bradykinin $(49.90 \%)$, and prostaglandins $(68.03 \%)$ compared to the diclofenac standard $5 \mathrm{mg} / \mathrm{kg}$. Chloroform extract of Gandarussa (Justicia gendarussa Burm .F.) produced $\beta$ sitosterol. $\beta$-sitosterol is one of the phytosterols which could help to reduce cholesterol by limiting the amount of cholesterol that entered the body, thereby increasing the prostate to help to reduce swelling (inflammation) using a mouse model of acute inflammation, $\beta$-sitosterol effect of leukocyte accumulate, cytokine doses, cytokine doses, and oxidative stress, showed potential anti-inflammatory activity by releasing histamine $(30.07 \%)$, serotonin and bradykinin $(52.25 \%)$ and prostaglandins $(69.43 \%)[7,8]$.

Extract of Gandarussa leaves (Justicia gendarussa Burm .F.) could reduce the level of urine F2-isoprostan which was carried out in experimental animals, was Wistar rat (Rattus norvegicus). F2isoprostane is a non-classical eicosanoid and has potent biological activity as a mediator of inflammation leading to pain perception. This study showed that the result of urine F2-isoprostane in rat decreased after 4 weeks in excessive physical treatment and Justicia gendarussa Burm $F$ leaf extract, was $5.46 \pm 0.655$ $\mathrm{ng} / \mathrm{ml}$ to $3.61 \pm 0.389 \mathrm{ng} / \mathrm{ml}[16]$.

The flavonoid compound of Gandarussa root (Justicia gendarussa Burm .F.) which has antiinflammatory activity is apigen. Methanol extract of root of Justicia gendarussa Burm .F. fractionated then isolated to obtain apigen compound. This study stated $89 \%$ inhibition of edema at dose of $10 \mathrm{mg} / \mathrm{kg}$ in carrageenan induced rat [17].

\section{Anti-cancer}

Anticancer potential of Gandarussa (Justicia gendarussa Burm .F.) with in vitro culture, ethanol, chloroform and ethyl acetate extracts were used to analyze cytotoxicity against liver carcinoma cell line (HepG2 ) and cervical cancer cell line (HeLa) by testing using multi tie tamper (MTT). The result showed that the ethanol extract of Gandarussa (Justicia gendarussa Burm .F.) has cytotoxicity activity against liver carcinoma cancer cell lines (HepG2) and (HeLa) with $\mathrm{IC}_{50}$ values $19.8 \mu \mathrm{g} / \mathrm{ml}$ and $43.8 \mu \mathrm{g} / \mathrm{ml}$. Chloroform and ethyl acetate extracts had $\mathrm{IC}_{50}$ values above 50 so they were unable to inhibit liver carcinoma (HepG2) and cervical cancer (HeLa) cells [18].

This study stated that Gandarussa leaves (Justicia gendarussa Burm .F.) using 96\% ethanol extract and aqueous extract showed the result of $\mathrm{LC}_{50}$ which were carried out using the Brine Shrimp Lethality Test (BSLT) method. 96\% ethanol extract of Gandarussa leaves (Justicia gendarussa Burm .F.) showed anticancer potential with $\mathrm{LC}_{50}$ valued 713,34 $\mu \mathrm{g} / \mathrm{ml}$. Aqueous extract of Gandarussa leaves (Justicia gendarussa Burm .F.) showed the greatest potential as an anticancer with the smallest LC ${ }_{50}$ valued 24.64 $\mu \mathrm{g} / \mathrm{ml}$. It showed that extract of Gandarussa leaves (Justicia gendarussa Burm .F.) has the potential to be developed as an anti-cancer [19].

\section{Antioxidant}

Gandarussa (Justicia gendarussa Burm .F.) has antioxidant activity with the amount of phenolic compounds in the methanol extract of Gandarussa leaves (Justicia gendarussa Burm .F.) $280.41 \pm 0.58$ $\mathrm{mg} / \mathrm{g}$ equivalent to gallic acid, while the flavonoid content was $165.52 \pm 0.65 \mathrm{mg} / \mathrm{g}$ equivalent to quarsetin. In the DPPH test, the $\mathrm{IC}_{50}$ value of Gandarussa (Justicia gendarussa Burm .F.) was $71,31 \pm 0.42 \mu \mathrm{g} / \mathrm{ml}$ while the $\mathrm{IC}_{50}$ value of ascorbic acid was $14.11 \pm 0.24 \mu \mathrm{g} / \mathrm{ml}$ [20].

\section{Sedativ and hypnotics}

The ethanol extract of Gandarussa (Justicia gendarussa Burm .F.) with doses of 250 and $500 \mathrm{mg} / \mathrm{kg}$ in rat could make sedative and hypnotic effect that was almost same as $3 \mathrm{mg} / \mathrm{kg}$ diazepam. The sedative and hypnotic activity of the ethanol extract of Gandarussa (Justicia gendarussa Burm .F.) was caused by chemical compounds such as flavonoids and terpenoids [21].

\section{Anti hiv}

Extraction of Gandarussa stem and bark ((Justicia gendarussa Burm .F.) was fractionated and isolated to obtain 2 compounds, justiprocumins A and B which believed that have anti-HIV activity. Both of these compounds were identified as glycosides arynalphthalide lignans (ANL) where arynalphthalide lignan was constituent of chemical that contributed to the activities of anti-HIV, giving a value of $\mathrm{IC}_{50} 21 \mathrm{~nm}$ better than the value of the $\mathrm{IC}_{50}$ drugs in clinical use of zidovudine (AZT) [22].

This study stated that $70 \%$ fractionated of Gandarussa ethanol extract (Justicia gendarussa Burm .F.) could be developed into anti-HIV drug because the ethanol fraction cannot induce IFN- $\gamma$ production. Based on the WHO standard which stated that the phytopharmaceutical dosage requirements for anti-HIV drug should not have IFN- interferon inducing activity [1].

\section{Toxicity}

In a study was conducted by Berna Elya examined the value of $\mathrm{LD}_{50}$ and liver function based on the activity of the aminotransferase enzym which was carried out on the test animals, male and female mice which were divided into 5 groups, group 1 as the control group, 2-5 were given the ethanol extract of 
Gandarussa leaves (Justicia gendarussa Burm .F.) with doses of 4,8,16, and $32 \mathrm{~g} / \mathrm{kg}$ (highest dose). The LD 50 test was determined by the number of deaths in the test group for 24 hours of treatment with one time giving of the test material. The result showed that the test material up to the highest dose was non-toxic with $\mathrm{LD}_{50}$ value $31.99 \mathrm{~g} / \mathrm{kg}$ bb (male group) and $27.85 \mathrm{~g} / \mathrm{kg}$ bb (female group). Measurement of aminotransferase enzyme activity using the colorimetric method showed that the liver function was not different between the control group and the test group by giving the test material solution with dose of $4 \mathrm{~g} / \mathrm{kg}-16 \mathrm{~g} / \mathrm{kg}$ bb [23].

\section{Male contraception drugs}

Research was conducted to determine the reversibility of the effects of Gandarussa leaves ethanol extract on the weight index of the reproductive organs of mice were testes, epididymis and vas deferens; the quality of the spermatozoa of mice were immotility, viability and abnormalities of spermatozoa and concentration of spermatozoa. This study used three doses of the extract were $0.065 \mathrm{mg} / \mathrm{kg} \mathrm{bb} ; 0.130 \mathrm{mg} / \mathrm{kg}$ $\mathrm{bb}$ and $0.195 \mathrm{mg} / \mathrm{kg}$ bb that were given for 22 days. To determine the reversibility of the effect, observations were made on one group of mice that were left alive for one month after giving the extract dose of $0.195 \mathrm{mg} / \mathrm{kg}$ bb. The result showed that the ethanol extract of Gandarusa leaves affected the index weight of the testes, epididymis and vas deferens with the largest reduction achieved by extract $0.195 \mathrm{mg} / \mathrm{kg} \mathrm{bb}$, significantly compared to control $(\mathrm{P}=0.000 ; \mathrm{a}=0.05)$ for all spermatozoa quality parameters. Gandarussa leaves ethanol extract could affect the spermatozoa concentration of mice, significantly compared to control $(\mathrm{P}=0.000 ; \mathrm{a}=0.05)$. Gandarussa leaves extract has $\mathrm{a}$ reversible effect on the index of reproductive organ weight and spermatozoa quality of mice. After one month of giving the extract, it could be seen from the absence of significant differences with control ( $\mathrm{P}$ index of testicular organ weight 0.479 ; $\mathrm{P}$ index of epididymal organ weight and vas deferens 0.614 ; P motility 0.484 ; $\mathrm{P}$ viability $0.992 ; \mathrm{P}$ abnormality $=1$; a 0.05 ), whereas the spermatozoa concentration showed an irreversible effect $(\mathrm{P}>0.05)$ [24].

\section{Conclusion}

Gandarussa (Justicia gendarusa Burm.F.) was a plant that has chemical compounds spread in every part of the plant, has benefits for treating various diseases such as antibacterial, analgesic, anthelmintic, anti-cancer anti-inflammatory, antioxidant, anti-HIV, toxicity, sedative hypnotic, and male contraceptive drugs.

\section{REFERENCES}

1. Sinansari, R., Bambang, P.E., \& Widiyanti, P. (2018). In silico Screening and Biological Evaluation of The Compounds of Justicia
Gendarussa Leaves Extract as Interferon Gamma Inducer: a study of anti-Human Immunodeficiency Virus (HIV) development. African journal of infectious diseases, 12(1S),140-7.

2. Syamsul, R, hidayat., \& M, Radome, Napitupulu, S, P. (2015). Kitab tumbuhan obat.Agriflo. Jakarta Timur.

3. Murugesan S. (2017). Phytochemical Evaluation, GC-MS Analysis of Bioactive Compounds and Antibacterial Activity Studies from Justicia gendarussa Burm. F. Leaf. Int. J. Pharmacogn. Phytochem. Res.9, 400-6.

4. Shikha, P., Latha, P.G., Suja, S.R., Anuja, G.I., Shyamal, S., Shine, V.J., Sini, S., Krishna Kumar, N.M., \& Rajasekharan, S. (2010). Antiinflammatory and antinociceptive activity of Justicia gendarussa Burm. f. Leaves, 1(4), 456-461.

5. Subramanian, N., Jothimanivannan, C., \& Moorthy K. (2012). Antimicrobial Activity and Preliminary Phytochemical Screening Of Justicia Gendarussa (Burm. F.) Against Human Pathogens. Asian Journal of Pharmaceutical and Clinical Research, 5(3), 229-33.

6. Arif, A., Islam H.M., Kanti, D.S., Arpona, H., Hemayet, H.M., \& Md H. (2012). Phytochemical Screening And Antibacterial Activity Of Different Fractions Of Justicia Gendarussa Root, Stem And Leaf, (5), 1036-1044

7. Phatangare, N.D., Deshmukh, K.K., Murade, V.D., Hase G.J., \& Gaje T.R. (2017). Isolation and Characterization of Phytol from Justicia Gendarussa Burm. F.-An Anti-Inflammatory Compound. International Journal of Pharmacognosy and Phytochemical Research, 9(6), 864-72.

8. Phatangare, N.D, Deshmukh, K.K, Murade, V.D, Naikwadi, P.H., Hase, D.P, Chavhan, M.J., \& Velis, HE. (2017). Isolation and Characterization of B-Sitosterol from Justicia Gendarussa Burm. F.-An Anti-Inflammatory Compound. International Journal of Pharmacognosy and Phytochemical Research, 9(9), 1280-7.

9. Ayob, Z., Jamil, S., Bohari S.P. (2017).Detection of Naringenin and Kaempferol in Justicia gendarussa Leaf Extracts by GC-FID. Sains Malaysiana.46 (3),457-61.

10. Sikder, M.A., Hossian, A.N., Siddique, A.B., Ahmed, M., Kaisar, M.A., \& Rashid, M.A. (2011). In Vitro Antimicrobial Screening Of Four Reputed Bangladeshi Medicinal Plants. Pharmacognosy Journal. 3(24), 72-6.

11. Venkatachalam, D., Rahman, A., Sunny, B., Jacob, J., Kuriyan, N., Raman, R., Vaniapurackal, R. (2019). Screening of Antimicrobial Activity of Various Extracts Of the Stem Justicia Gendarussa. Asian Journal of Research in Medical and Pharmaceutical Sciences, 19, 1-7.

12. Saha, M.R., Debnath, P.C., Rahman, M.A., \& Islam MA. (2012). Evaluation of In Vitro Anthelmintic Activities of. Leaf And Stem Extracts 
of Justicia Gendarussa. Bangladesh Journal of Pharmacology, 7(1), 50-3.

13. Hesturini, R.J., Herowati, R., \& Widodo, G.P. (2018). Uji Aktivitas Analgetika Fraksi-Fraksi Ekstrak Etanol Daun Gandarusa (Justicia gendarussaBurm. f) dengan Metode Tail Flick. Jurnal Farmasi Indonesia, 15(1), 13-7.

14. Varma, R.S., Ashok, G., Vidyashankar, S., Patki, P., \& Nandakumar KS. (2011). Ethanol Extract of Justicia Gendarussa Inhibits Lipopolysaccharide Stimulated Nitric Oxide and Matrix Metalloproteinase-9 Expression in Murine Macrophage. Pharmaceutical biology, 49 (6), 64852.

15. Kavitha, S.K., Viji, V., Kripa, K., \& Helen, A. (2011). Protective Effect Of Justicia Gendarussa Burm. F. On Carrageenan-Induced Inflammation. Journal of Natural Medicines, 65(3-4), 471-9.

16. Akpriyanti, D.I., Pangkahila, W., \& Aman, I.G. (2017). Pemberian Ekstrak Daun Gandarusa (Justicia gendarussa Burm. f.) Menurunkan Kadar F2-isoprostan Urin Tikus Wistar (Rattus norvegicus) Jantan yang Diinduksi Latihan Fisik Berlebih. Jurnal Biomedik: JBM, 3; 9(3).

17. Kumar, K.S., Sabu, V., Sindhu, G., Rauf, A.A, \& Helen. A. (2018). Isolation, Identification and Characterization of Apigenin From Justicia Gendarussa and Its Anti-Inflammatory Activity. International immunopharmacology.59, 157-67.

18. Mangai, A, S. (2017). A Cytotoxic Approach of Justica Gendarussa Burm.F Against Human Cancer Cell Lines A Cytotoxic Approach of Justica Gendarussa Burm.F Against Human Cancer Cell Lines. International research journal of pharmacy, $8(12)$.
19. Widodo, A., Khumaidi, A., \& Lasongke, P.F. (2019).Toksisitas Ekstrak Etanol dan Ekstrak Air dari Daun Jotang Kuda (Synedrella nodiflora (L.) Gaertn.), Daun Gandarusa (Justicia Gendarussa Burm. F.), dan Daun Pulutan (Urena lobata L.) dengan Brine Shrimp Lethality Test. Jurnal Farmasi Galenika (Galenika Journal of Pharmacy)(e-Journal), 5(2),198-205.

20. Mondal, M., Hossain, M.M., Rahman, M.A., Saha, S., Uddin, N., Hasan, M.R., Kader, A., Wahed, T.B., Kundu, S.K., Islam, M.T., \& Mubarak, M.S. (2019). Hepatoprotective and Antioxidant Activities of Justicia Gendarussa Leaf Extract In Carbofuran-Induced Hepatic Damage In Rats. Chemical Research in Toxicology, 32(12), 2499508.

21. Subramanian, N., Jothimanivannan, C., Senthilkumar, R., \& Kameshwaran S. (2014). Sedative and Hypnotic Activity of Ethanolic Extract of Justicia Gendarussa Burm. Int $J$ Phytopharmacol, 5, 354-7.

22. Zhang, H.J., Rumschlag-Booms., E., Guan, Y.F., Liu, K.L., Wang, D.Y., Li, WF., Cuong N.M., Soejarto, D.D., Fong, H.H., Rong, L. (2017). AntiHIV diphyllin glycosides from Justicia gendarussa. Phytochemistry, 136, 94-100.

23. Elya, B., \& Amin, J. (2011). Toksisitas Akut Daun Justicia Gendarussa Burm. makara journal of science. 2.

24. Bagia, N. L., Lestari, F., \& Choesrina, R. (2011). Efek Ekstrak Etanol Daun Gandarusa (Justicia Gendarusa Burm. F) Terhadap Sistem Reproduksi Dan Kualitas Spermatozoa Serta Reversibilitasnya Pada Mencit Jantan Galur Swiss Webster. Prosiding SNaPP: Sains, Teknologi, 2(1), 63-70. 